\title{
RA?EGA
}

O ESPACYO GEOGRÁFICO EM ANÁLISE

\section{INFLUÊNCIA DA VEGETAÇÃO EM VARIÁVEIS CLIMÁTICAS: ESTUDO EM BAIRROS DA CIDADE DE TERESINA, PIAUÍ}

\author{
INFLUENCE OF VEGETATION IN VARIABLE CLIMATE: STUDY \\ IN QUARTERS OF TERESINA CITY, PIAUÍ
}

\author{
Marcos Machado de Albuquerque \\ Universidade Federal do Piauí - UFPI \\ Professor do Departamento de Transportes \\ Teresina, Pl, Brasil \\ e-mail:marcospi@ufpi.edu.br \\ Wilza Gomes Reis Lopes \\ Professora do Departamento de Construção Civil e Arquitetura e do \\ Programa de Pós Graduação em Desenvolvimento e Meio Ambiente \\ Universidade Federal do Piauí - UFPI \\ Teresina, Pl, Brasil \\ e-mail: izalopes@uol.com.br
}

\section{Recebido em: 02/02/2015}

Aceito em: 11/04/2016

\section{Resumo}

O processo de urbanização tem interferido nas condições ambientais, promovendo a substituição de estruturas naturais por equipamentos urbanos. Como consequências impactantes têm surgido diversas formas de poluição, gerando crises ambientais nos mais diferenciados ecossistemas. O conforto térmico está diretamente relacionado às condições ambientais, tais como, a temperatura, a umidade do ar e ação dos ventos, que são modificadas, pela impermeabilização do solo e pela ausência de vegetação. Neste estudo, o objetivo foi determinar a influência das áreas verdes urbanas na temperatura da cidade de Teresina, Piauí, comparando dados climáticos coletados em locais arborizados, com dados coletados em regiões da cidade com menos vegetação, destacando a importância dessas áreas para a melhoria da qualidade ambiental do espaço urbano. Desenvolvida em Teresina, a pesquisa enfoca os bairros Jóquei Clube, Pedra Mole e Dirceu Arcoverde. Foram realizadas medições simultâneas de temperatura e umidade relativa do ar, nos horários de 9, 15 e $21 \mathrm{~h}$ em locais com vegetação e locais sem vegetação com características áridas, abrangendo os períodos seco e chuvoso, durante sete dias consecutivos. Os resultados demonstraram que o bairro com maiores 
ALBUQUERQUE, M. M. ; LOPES, W. G. R.

INFLUÊNCIA DA VEGETAÇÃO EM VARIÁVEIS CLIMÁTICAS: ESTUDO EM BAIRROS DA

CIDADE DE TERESINA, PIAUÍ

áreas verdes apresentou os menores valores de temperatura. Nos três bairros as temperaturas mais elevadas foram registradas em pontos sem vegetação, fato que caracteriza a relevância da vegetação na redução da temperatura ambiente.

Palavras-chave: áreas verdes urbanas; urbanização; Clima Urbano.

\begin{abstract}
The process of urbanization has interfered in environmental conditions, promoting the replacement of natural structures for urban equipments. How shocking consequences have arisen the various forms of pollution, creating environmental crises in more differentiated ecosystems. The Thermal comfort is directly linked to environmental conditions such as the temperature and the humidity of the air, which are modified by soil sealing and the absence of vegetation. The study aimed to determine the influence of urban green land in the temperature of Teresina-PI, comparing climate data collected in woodlands with data collected in regions of the city with lower vegetation index, highlighting the importance of these areas for improve the environmental quality of urban space. The research was conducted in city of Teresina, Piauí, focusing on neighborhoods Pedra Mole, Jóquei Clube and Dirceu Arcoverde. During the hours of 9,15 and $21 \mathrm{~h}$, measurements were made of climatic variables in five places with abundant vegetation and arid characteristics, covering the rainy and dry seasons during seven consecutive days. The results showed that the neighborhood with more green areas showed the lowest temperature. In three neighborhoods, higher temperatures were recorded at points devoid of reducing of vegetation, apparel featuring the importance of vegetation in reduction of environment temperature.
\end{abstract}

Key-words: Urban green areas; urbanization; urban climate

\title{
1. INTRODUÇÃO
}

O intenso processo de urbanização tem interferido de forma marcante nas condições ambientais, promovendo a substituição de valores e de estruturas naturais por equipamentos urbanos. Como consequências impactantes têm surgido as mais variadas formas de poluição, gerando crises ambientais nos mais diferenciados ecossistemas, alterando a qualidade de vida do planeta Terra.

Os problemas ambientais são diretamente proporcionais ao crescimento da população, podendo ser os mais variados. Entre os problemas urbanos, Silva e Travassos (2008) destacam a carência e a precariedade de habitações, 
a falta de infraestrutura de saneamento, destinação inadequada de resíduos sólidos. Além disso, as autoras se referem, também, à redução de áreas verdes e aumento da impermeabilização do solo, que podem contribuir para o aumento de temperatura e das enchentes nas áreas urbanas.

A urbanização, inevitavelmente, provoca alterações no microclima e atmosfera da cidade, no ciclo hidrológico, no relevo, na vegetação e na fauna, sendo que as áreas verdes podem atuar na redução de temperatura. Barbosa, Barbirato e Vecchia (2003), em estudo na cidade Maceió, Alagoas, observaram aumento de até $2,5 \stackrel{\circ}{\circ}$ nas temperaturas encontradas em áreas com e sem vegetação. Também, Abreu e Labaki (2010) comprovaram a influência das árvores na redução de temperatura e melhoria do conforto térmico em seu entorno imediato, em pesquisa desenvolvida na cidade de Campinas, São Paulo, enfocando espécies vegetais diversas, como ipê-amarelo (Tabebuia chrysotricha), jambolão (Syzygium cumini) e a mangueira (Mangifera indica).

O uso do solo no meio urbano, na visão de Lombardo (1997), diretamente relacionado às atividades do ser humano, torna a cidade um fator modificador do clima regional, definindo condições do clima local. Neste sentido, Souza, Silva e Silva (2016, p. 35), em estudo realizado na cidade de João Pessoa, Paraíba, constataram que, "a temperatura da superfície é maior em áreas densamente urbanizadas, onde há predomínio de concreto e solo exposto, e menor em regiões onde há certa quantidade de vegetação e áreas menos adensadas".

Além de protegerem o solo da impermeabilização, facilitando a infiltração das águas pluviais e reduzindo o escoamento superficial, as áreas verdes urbanas controlam a poluição atmosférica e melhoram, também, as condições climáticas, reduzindo os extremos das temperaturas. Proporcionam melhoria ao ambiente da cidade e benefícios para os seus habitantes. Além disso, apresentam funções ecológicas, sociais, estéticas, educativas e psicológicas.

Como a vegetação urbana é fator importante para a melhoria do conforto ambiental, pesquisas nesta área são necessárias para subsidiar a elaboração 


\section{INFLUÊNCIA DA VEGETAÇÃO EM VARIÁVEIS CLIMÁTICAS: ESTUDO EM BAIRROS DA}

CIDADE DE TERESINA, PIAUÍ

de projetos urbanísticos e paisagísticos, voltados para a melhoria ambiental dos aglomerados humanos.

É comum encontrar nas áreas urbanas locais que apresentam alto grau de degradação do ambiente, caracterizado pelo excesso de elementos artificiais e ausência de vegetação. Conjuntamente com o crescimento urbano acelerado, a falta de planejamento tem ocasionado forte diminuição da qualidade ambiental das cidades, afetando diretamente a qualidade de vida da população urbana. A falta de integração entre os equipamentos urbanos e áreas verdes tem tornado o ambiente urbano cada vez mais desagradável.

Nas últimas décadas, tem ocorrido na cidade de Teresina, como acontece em grande parte das cidades brasileiras, o aumento da ocupação do solo urbano, acarretando, inevitavelmente, a retirada da vegetação nativa de grandes áreas, substituída por equipamentos urbanos. Além disso, modificouse o costume da população de plantar árvores de grande porte, em seus jardins e quintais, com o objetivo de sombreamento. $O$ que se observa agora é a impermeabilização cada vez maior dessas áreas, reduzindo, portanto, as áreas arborizadas e permeáveis da cidade, afetando o aumento de temperatura e, consequentemente, a qualidade de vida da população.

Considerada como uma das cidades mais quentes do Brasil, Teresina chega a apresentar temperaturas de até $40{ }^{\circ} \mathrm{C}$, nos períodos mais quentes. Segundo Silveira (2007, p. 87), "a região recebe forte radiação solar durante todo o ano, devido à proximidade do Equador. A baixa altitude é outro fator que, associado à baixa latitude, faz com que sejam registradas altas temperaturas na região o ano todo".

Em função das elevadas temperaturas, Andrade (2005, p. 188) salienta a necessidade, em Teresina, "[...] da presença de árvores, tanto pela produção de sombras quanto pela possibilidade de um maior controle sobre os problemas gerados pela grande radiação solar e, consequentemente, pela temperatura do ar".

Diante deste cenário, questiona-se a relação entre as áreas verdes urbanas e variáveis climáticas em cidades de clima quente seco. O objetivo 
deste trabalho foi determinar a influência das áreas verdes na temperatura e umidade do ar, comparando dados climáticos coletados em locais com vegetação com dados coletados em regiões sem vegetação, na cidade de Teresina, Piauí, destacando a importância dessas áreas para a melhoria da qualidade ambiental do espaço urbano.

\section{AMBIENTE URBANO E VEGETAÇÃO}

$\mathrm{Na}$ visão de Duarte e Serra (2003), as cidades são compostas por mosaicos de diferentes microclimas, caracterizados por pequenas ilhas de calor, bolsões de poluição atmosférica e diferenças locais no fluxo dos ventos.

Uma das razões para a formação de ilhas de calor está relacionada, segundo Gartland (2010), aos materiais de construção, comumente utilizados, que são impermeáveis e estanques, prejudicando a dissipação do calor do sol, devido à baixa umidade. Segundo Frota e Shiffer (p. 66), as "ilhas de calor, basicamente, são geradas a partir das modificações impostas à drenagem do solo, notadamente pelo seu revestimento por superfície de concreto e asfalto".

Freitas e Dias (2005, p. 355), ao se referirem à formação de ilha de calor, apontam como um dos motivos "a concentração relativamente alta de fontes de calor nas cidades", destacando que, "[...] as propriedades térmicas dos materiais das construções urbanas também facilitam a condução de calor mais rapidamente que o solo e a vegetação das áreas rurais, contribuindo para aumento no contraste de temperatura entre essas regiões".

Estudos realizados sobre clima urbano têm constatado a existência de relação entre o uso e ocupação do solo e distribuição da temperatura. Lombardo (1985), ao estudar a ilha de calor na metrópole paulista, verificou que as temperaturas mais amenas são observadas em regiões residenciais, em que geralmente a presença de cobertura vegetal é mais acentuada, enquanto que, nas regiões comerciais e industriais, onde há maior concentração de pessoas, as temperaturas são mais elevadas. Em pesquisa realizada por Almeida Junior (2005), em Cuiabá-MT, ficou constatado que as áreas arborizadas reduzem a temperatura do local. 
As áreas com vegetação são responsáveis, entre outros aspectos, pela melhoria do conforto ambiental, atuando na redução da temperatura e da poluição sonora, contribuindo, ainda, para estabilidade emocional e conforto psicológico, além de proporcionar ambientes para lazer, descanso e recreação. Para Mascaró et al. (2000), o uso da vegetação é um recurso eficiente contra o calor nas cidades tropicais úmidas, pois, além de fornecer sombreamento, permite a passagem da brisa local e absorve de maneira eficaz a radiação térmica de onda longa sobre as folhas refrescadas pela evaporação.

Lamas (2004, p. 106) valoriza a presença de vegetação nas cidades, afirmando que a as estruturas verdes "caracterizam a imagem da cidade; têm individualidade própria; desempenham funções precisas: são elementos de composição e do desenho urbano; servem para organizar definir e conter espaços". Ainda, segundo Lamas (2004, p.106), as "árvores e vegetação existentes [...] são de grande importância na forma urbana, no controle do clima e qualificação da cidade".

A vegetação desempenha funções importantes para o recinto urbano, pois segundo Mascaró e Mascaró (2002), ela ajuda no controle do clima e da poluição, contribui para a conservação da água, na redução da erosão e na economia da energia, além de promover a biodiversidade e o bem-estar dos habitantes. Neste sentido, Dacanal; Labaki e Silva (2010, p. 116) afirmam que "o elemento vegetação aparece como parte integrante do projeto urbano, reconhecendo-se sua importância na alteração das condições microclimáticas e, consequentemente, no desempenho térmico das construções".

Como área verde urbana considera-se àquela superfície permeável e em que há predomínio de vegetação arbórea, englobando as praças, os jardins públicos e os parques urbanos. Os canteiros centrais de avenidas e os trevos e rotatórias de vias públicas, que exercem apenas funções estéticas e ecológicas, devem, também, conceituar-se como área verde (LIMA et al., 1994).

Investigações realizadas em vários locais do país atestaram o efeito da vegetação para a melhoria do microclima urbano. Abreu (2008, p. 143), em 


\section{INFLUÊNCIA DA VEGETAÇÃO EM VARIÁVEIS CLIMÁTICAS: ESTUDO EM BAIRROS DA}

CIDADE DE TERESINA, PIAUÍ

estudo na cidade de Campinas, São Paulo, constatou que "a arborização contribui significativamente para a melhoria do microclima, em ambientes externos, mesmo ao sol”, sendo a vegetação responsável, além da redução de temperatura, pela umidificação do local por meio da evapotranspiração. Em pesquisa similar, realizada na cidade de Palmas, Tocantins, Paz (2009) identificou que os pontos de medição, situados próximos a ambientes com mais vegetação foram os que apresentaram menores valores de temperatura, enquanto que, aqueles próximos a ambientes mais urbanizados, com pouca vegetação, apresentaram temperaturas mais elevadas. Foi observada diferença de até $4,1^{\circ} \mathrm{C}$, a menos, nos locais mais arborizados. Dessa forma, é possível perceber a importância do uso da vegetação para a redução da temperatura do ar em ambientes urbanos.

\section{A CIDADE DE TERESINA}

O município de Teresina localiza-se na mesoregião Centro-norte do estado do Piauí à margem direita do Rio Parnaíba, distando cerca de 350 km do litoral piauiense. A cidade de Teresina, capital do Estado do Piauí, tem grande parte de sua área situada entre dois rios, Poti e Parnaíba, apresentando altitude média de 72,00 m, situa-se próxima à linha do equador, a 0505'12”, de latitude sul e longitude oeste, de 4248'42" (CASTELO BRANCO; ARAÚJO, 2001).

A população do município, pelo censo de 2010, era composta de 814.230 habitantes, sendo que a população estimada, em 2015, foi de 844.245 habitantes, que ocupam área de 1.391,97 km², possuindo, atualmente, 113 bairros (IBGE, 2010), distribuídos em quatro zonas administrativas: CentroNorte, Sul, Leste e Sudeste (Figura 1). 


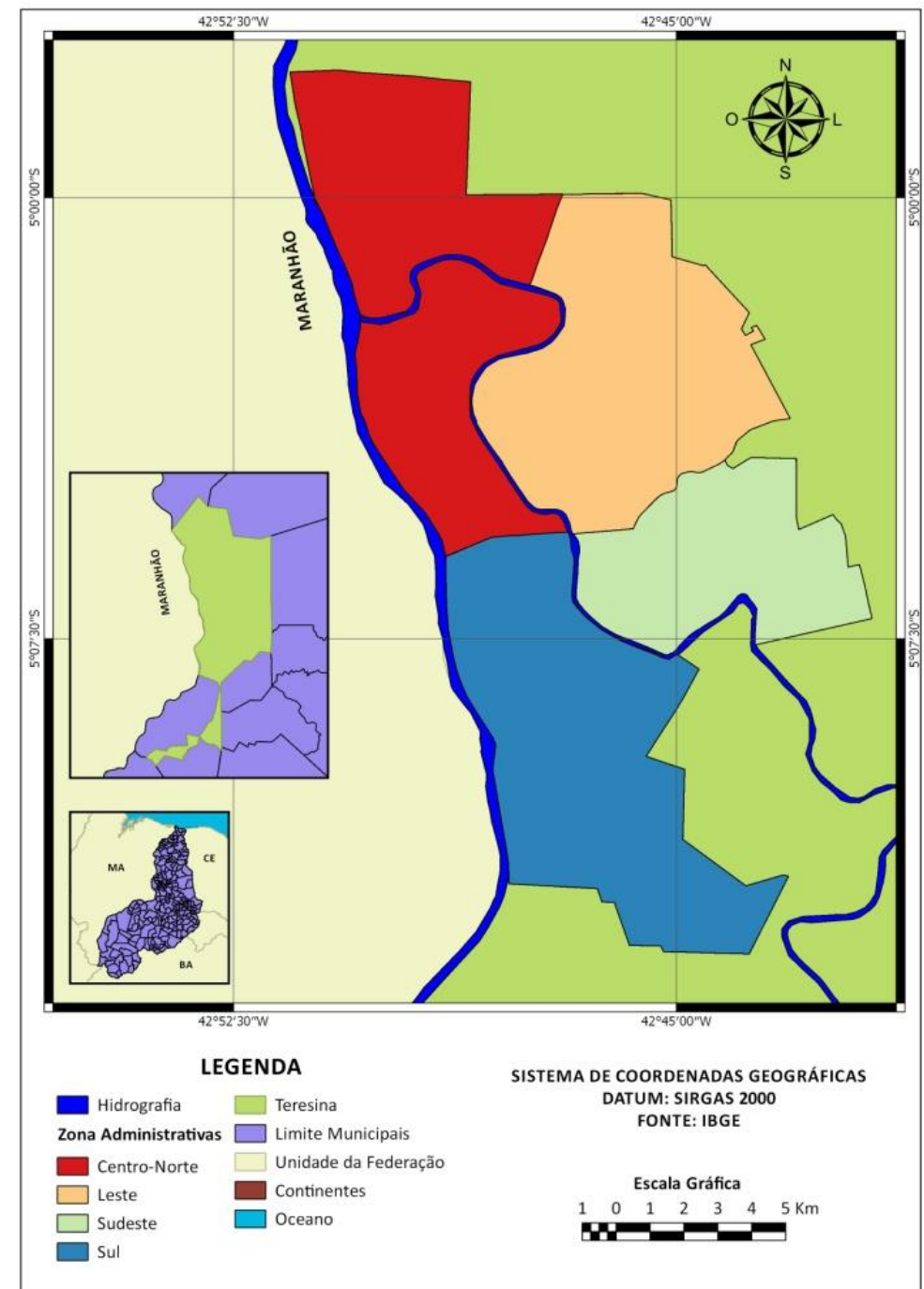

Figura 1. Cidade de Teresina e sua divisão por zonas administrativas Fonte: adaptado do IBGE (2010) apud Silva (2015, p. 34)

Segundo a classificação de Köppen, o clima de Teresina, é tropical megatérmico (AW), "com amplitude térmica anual menor que $5{ }^{\circ} \mathrm{C}$. Caracterizase por ser um clima tropical continental, com duas estações bem definidas: uma chuvosa, no $1^{\circ}$ semestre (de janeiro a maio) e outra seca, no $2^{\circ}$ semestre (de julho a novembro)" (SILVEIRA, 2007, p. 86).

Sobre os ventos da região, Silveira (2007, p. 89) afirma que, "são fracos, com velocidade média anual de $1,4 \mathrm{~m} / \mathrm{s}$ e direção predominante sudeste. Nos meses de julho a outubro, a velocidade média é um pouco elevada $1,7 \mathrm{~m} / \mathrm{s}$, diminuindo para 1,2 m/s de janeiro a maio". A autora destaca, ainda, "a elevada presença de calmarias, variando entre 40 e $60 \%$ ao ano". Enquanto que, em 
ALBUQUERQUE, M. M. ; LOPES, W. G. R.

INFLUÊNCIA DA VEGETAÇÃO EM VARIÁVEIS CLIMÁTICAS: ESTUDO EM BAIRROS DA

CIDADE DE TERESINA, PIAUÍ

Fortaleza, segundo dados apresentados por Paiva (2010 p. 84), "a velocidade do ar apresenta uma média anual de $3,7 \mathrm{~m} / \mathrm{s}$ ", sendo que, no segundo semestre "os ventos intensificam registrando valores mais acentuados nos meses de setembro $(4,7 \mathrm{~m} / \mathrm{s})$ e outubro $(4,6 \mathrm{~m} / \mathrm{s})$ ). Acredita-se, então, que em Teresina, o fator vento tem contribuição reduzida na dissipação do calor.

A zona urbana de Teresina apresenta relevo plano em quase toda a sua área, com exceção de algumas regiões, como é o caso do bairro Monte Castelo na zona Sul (elevadas altitudes) e na zona Leste destacam-se os bairros Satélite, Vila Bandeirante e Socopo, localizados sobre uma superfície acidentada com a presença de morros.

No espaço urbano de Teresina, segundo Lima (2002, p. 185),

\begin{abstract}
"ainda restam alguns pontos-relíquia das matas verdes naturais, que são conservadas como unidades ambientais: o Parque da Cidade (Primavera), o Parque de Teresina (Mocambinho), o Zoobotânico (zona nordeste da cidade) e alguns trechos que margeiam os Rios Parnaíba e Poti, entre outros de menor expressão, considerados como áreas de conservação/preservação. Esses ecossistemas são compostos por imponentes árvores como angicos brancos, babaçuais, caneleiros e tantas outras espécies que compõem as faixas de transição da floresta semidecídua x cerrado x caatinga."
\end{abstract}

Segundo Sales (2003), à época da fundação da cidade, a vegetação nativa predominante era composta por palmeiras de babaçu, as quais ocupavam os vales úmidos dos rios Poti e Parnaíba, vegetação esta que no decorrer dos anos vem sendo substituída por equipamentos urbanos.

Em estudo realizado por Machado, Pereira e Andrade (2010), sobre a cobertura vegetal existente, em Teresina, foi constatada a redução de vegetação do período de 2005/2006, em relação ao ano de 2000 , de $45,56 \%$ para $39,76 \%$, embora a região Sul da cidade tenha passado de $39,60 \%$ para 40,84\% (Tabela 1). 
ALBUQUERQUE, M. M. ; LOPES, W. G. R.

INFLUÊNCIA DA VEGETAÇÃO EM VARIÁVEIS CLIMÁTICAS: ESTUDO EM BAIRROS DA

CIDADE DE TERESINA, PIAUÍ

Tabela 1. Cobertura vegetal por região administrativa em Teresina - PI, para os anos de $2000 \mathrm{e}$ $2005 / 2006$

\begin{tabular}{c|c|c|c|c|c}
\hline \multirow{2}{*}{ REGIÃO } & $\begin{array}{c}\text { Área Total } \\
\text { da Região } \\
\left(\mathbf{K m}^{2}\right)\end{array}$ & $\begin{array}{c}\text { Área de } \\
\text { Cobertura } \\
\text { Vegetal }\left(\mathbf{K m}^{2}\right)\end{array}$ & $\begin{array}{c}\text { Percentual } \\
\text { Cobertura } \\
\text { Vegetal (\%) }\end{array}$ & $\begin{array}{c}\text { Área de } \\
\text { Cobertura } \\
\text { Vegetal }\left(\mathbf{k m}^{2}\right)\end{array}$ & $\begin{array}{c}\text { Percentual } \\
\text { Cobertura } \\
\text { Vegetal (\%) }\end{array}$ \\
\cline { 3 - 6 } & \multicolumn{2}{|c|}{$\mathbf{2 0 0 0}$} & \multicolumn{2}{c}{$\mathbf{2 0 0 5 / 2 0 0 6}$} \\
\hline \hline Centro-Norte & 68,11 & 31,57 & 46,35 & 22,54 & 33,09 \\
Sul & 70,09 & 27,76 & 39,60 & 28,62 & 40,84 \\
Sudeste & 29,62 & 15,57 & 52,56 & 11,97 & 40,39 \\
Leste & 63,60 & 30,53 & 48,01 & 28,88 & 45,40 \\
Total & $\mathbf{2 3 1 , 4 3}$ & $\mathbf{1 0 5 , 4 3}$ & $\mathbf{4 5 , 5 6}$ & $\mathbf{9 2 , 0 1}$ & $\mathbf{3 9 , 7 6}$ \\
\hline
\end{tabular}

Fonte: adaptado de Machado; Pereira; Andrade (2010)

Feitosa et al. (2011, p. 68), analisando a modificação da vegetação na cidade de Teresina, no período de 1989 a 2009, concluíram que "A área ocupada aumentou, em 2009, 60,4 \%, em relação a 1989, atingindo $113,9 \mathrm{~km}^{2}$, enquanto a vegetação foi suprimida". Foi constatado, ainda, o aumento dos valores de temperatura média do ar, na cidade de Teresina, no ano de 2010 em relação ao período de 1980 a 2009 (BASTOS; ANDRADE JÚNIOR, 2011), o que pode estar relacionado à redução das áreas com vegetação na cidade.

\section{METODOLOGIA}

\subsection{Caracterização da área objeto de estudo}

Para a definição dos locais a serem estudados foi usado como critério, a escolha de bairros com características diferentes, principalmente, em relação à quantidade de áreas com vegetação e densidade habitacional. Com o intuito de reduzir os fatores influenciadores na temperatura e umidade do ar nas regiões estudadas, foi considerada, ainda, a direção predominante dos ventos, a sua proximidade e a sua posição (lado direito) em relação ao rio Poti.

A pesquisa foi desenvolvida enfocando os bairros Pedra Mole e Jóquei Clube na Zona Leste e Dirceu Arcoverde, na Zona Sudeste, da cidade de Teresina, Piauí, e que apresentam características diversas (Figura 2).

Assim, o Bairro Pedra Mole (PM), ainda, possui extensas áreas verdes e baixa densidade populacional, enquanto o Bairro Jóquei Clube (JC) está em fase de verticalização, mas apresentando, ainda, significativas áreas verdes. Já, o Bairro Dirceu Arcoverde (DA) possui alta densidade habitacional e pouca área verde. 


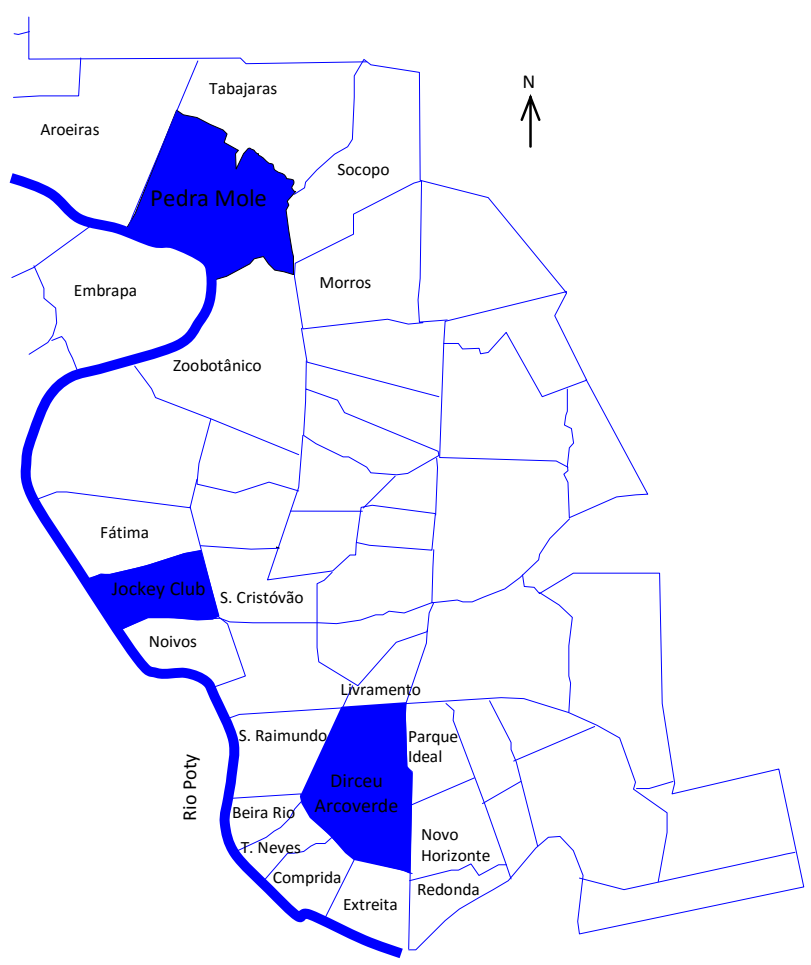

Figura 2. Mapa das Zonas Leste e Sudeste de Teresina, com destaque para os bairros estudados

Fonte: Mapa de Teresina - bairros [2010], adaptado pelos autores

\section{Bairro Pedra Mole}

No bairro Pedra Mole foram observadas áreas com ocupação e características distintas. A área central, onde foi realizada a pesquisa (Figura 3), ocupada pelo conjunto residencial Pedra Mole, que deu origem ao nome do bairro, é composta por quadras projetadas e delimitadas por ruas pavimentadas com largura de 9,0 m, incluindo os passeios laterais (calçada).

Os lotes com área em torno de $160,00 \mathrm{~m}^{2}(8,00 \mathrm{~m} \times 20,00 \mathrm{~m})$, atualmente, apresentam taxa de ocupação próxima de 100\%, por construções com apenas um pavimento e baixo padrão. Já a região do entorno da área central apresenta vasta área, composta de imóveis de forma irregular, com extensas áreas de vegetação de grande porte, como se visualiza na Figura 3. 


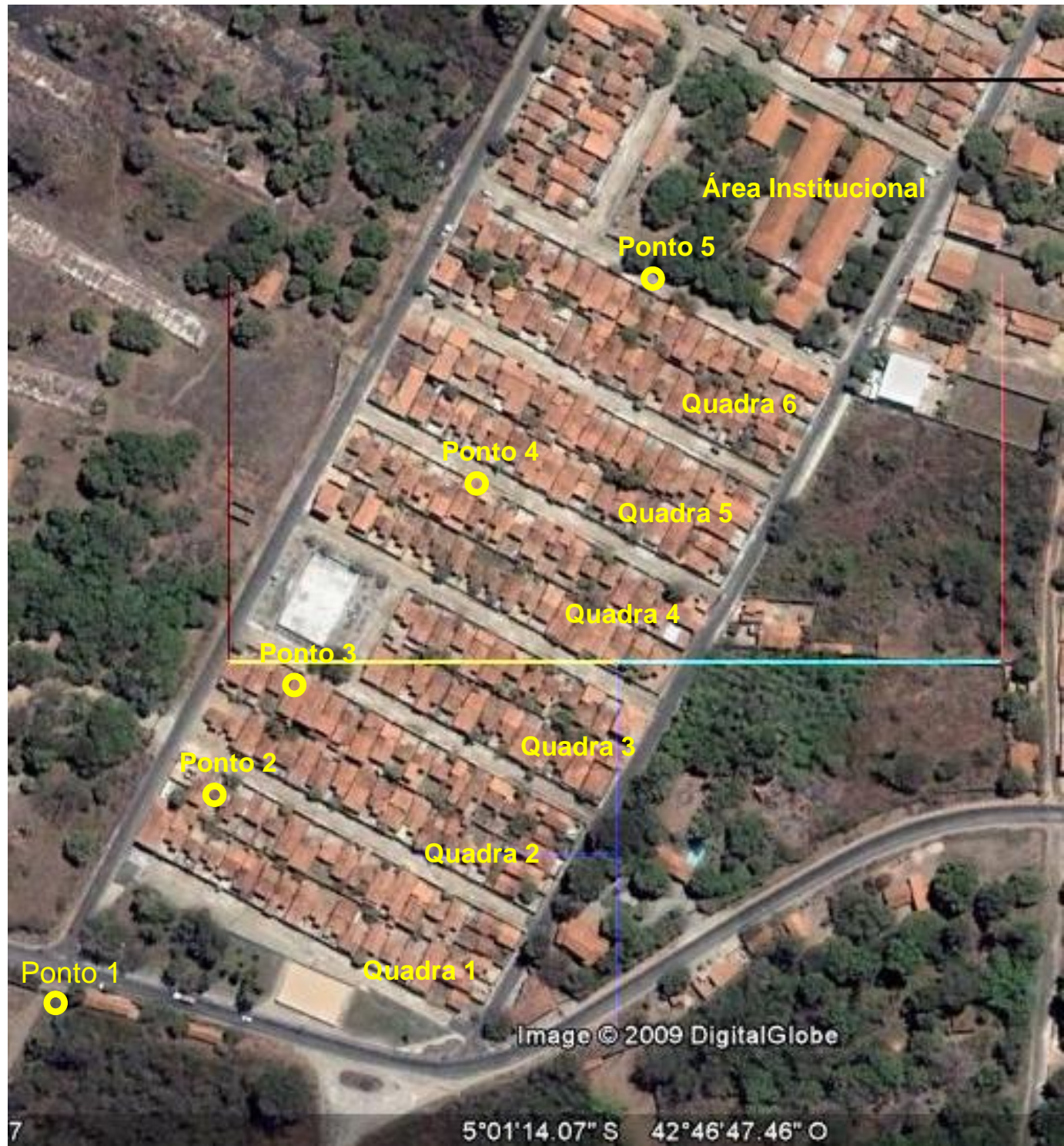

Figura 3. Vista aérea do bairro Pedra Mole e localização dos pontos de coleta

Fonte: Google Earth, 2009

\section{Bairro Jóquei Clube}

Situado na zona Leste de Teresina e à margem direita do Rio Poti, o bairro Jóquei Clube teve sua formação iniciada em 1952, com a construção do Jockey Club do Piauí, direcionado para a prática de corridas de cavalos. Ao mesmo tempo foi implantado o primeiro loteamento residencial urbano no entorno do clube, dando início à urbanização da zona Leste da cidade. $O$ processo se intensificou com a construção da primeira ponte rodoviária sobre o rio Poti em 1956, permitindo a interligação do bairro com o centro urbano da 
cidade. Na Figura 4 se vê trecho do bairro Jóquei Clube, com a localização dos pontos de coleta.

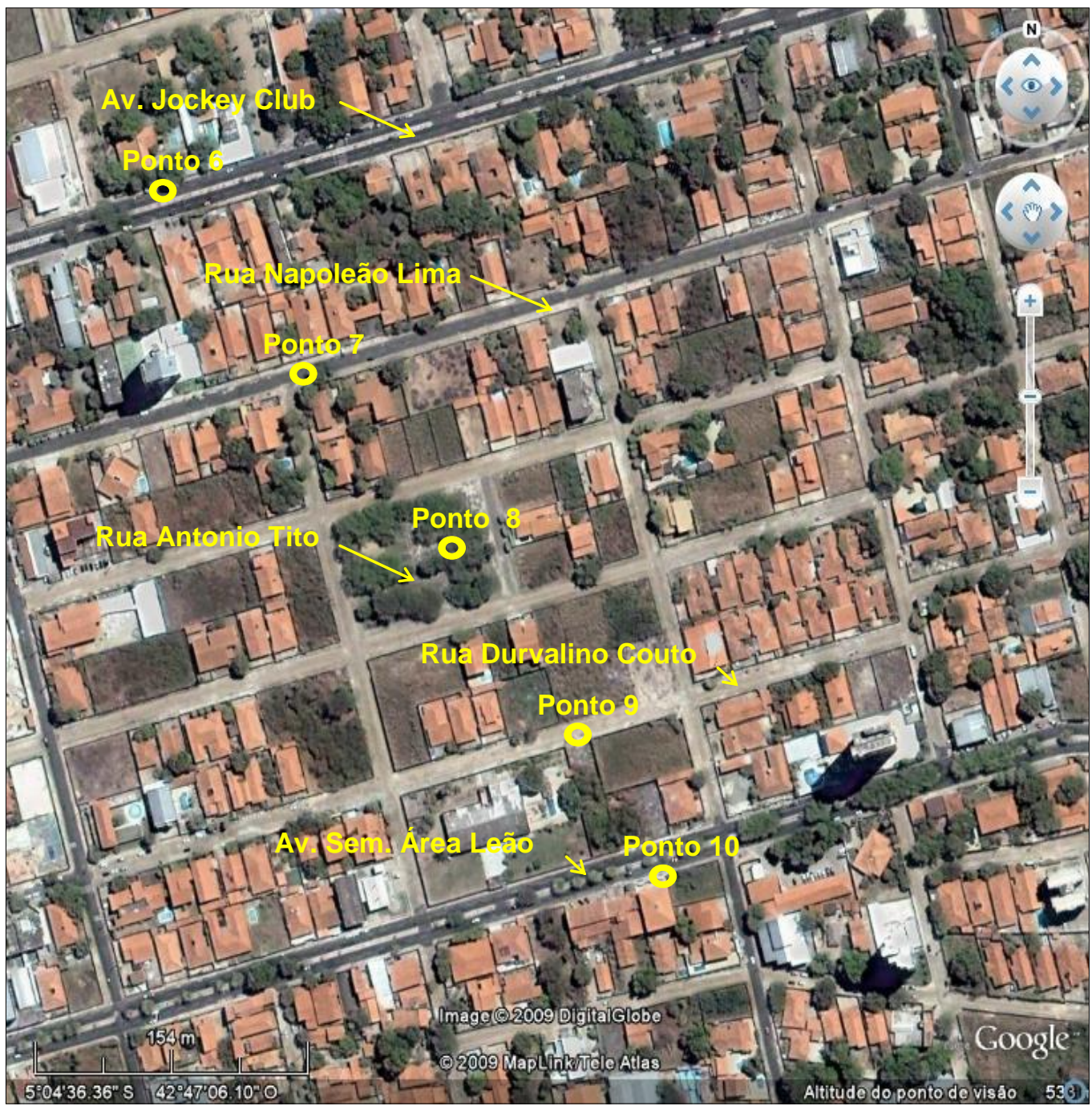

Figura 4. Vista Aérea de trecho do Bairro Jóquei Clube e Pontos de Coleta

Fonte: Google Earth, 2009

O bairro Jóquei Clube possui vias, em sua totalidade, pavimentadas (Asfáltica / Poliédrica), que delimitam quadras em formatos bastante regulares. O bairro teve sua ocupação em função da implantação de dois tipos de loteamentos: o primeiro a sul da Avenida Jóquei Clube, com quadras formadas por lotes de área em torno de 420,00 $\mathrm{m}^{2}$ (12,00 m x 35,00 m); o segundo situado ao norte da Avenida Jóquei Clube apresentava quadras com poucos lotes, em torno de quatro, de dimensões bem maiores. A região passa por 
acelerado processo de verticalização, apresentando a ocupação do solo de forma mista.

\section{Bairro Dirceu Arcoverde}

O bairro Dirceu Arcoverde se expandiu com o surgimento na década de 1980, de diversos conjuntos habitacionais, loteamentos e vilas em seu entorno. Sua população aumentou sensivelmente, juntamente com o desenvolvimento social, econômico e cultural. Conhecido popularmente, também, por Itararé, é o mais populoso da cidade, conta de acordo com o último censo, 37.443 habitantes (IBGE, 2010).

Observa-se que a região teve ocupação uniforme com construções de casas de conjunto popular, em quadras projetadas e bem definidas. Estas quadras são compostas por lotes padrões com área de $200,00 \mathrm{~m}^{2}(10,00 \mathrm{x}$ 20,00 m).

Com exceção dos trajetos de ônibus e das avenidas, que possuem pavimentação com revestimento asfáltico, as vias do bairro são pavimentadas com pedras poliédricas e possuem largura de $9,00 \mathrm{~m}$. O bairro tem como característica, a presença de lotes de dimensões reduzidas com elevada taxa de ocupação, observada em visita ao local

$\mathrm{Na}$ figura 5 estão marcados os locais dos pontos de coleta das variáveis climáticas do bairro Dirceu Arcoverde. 


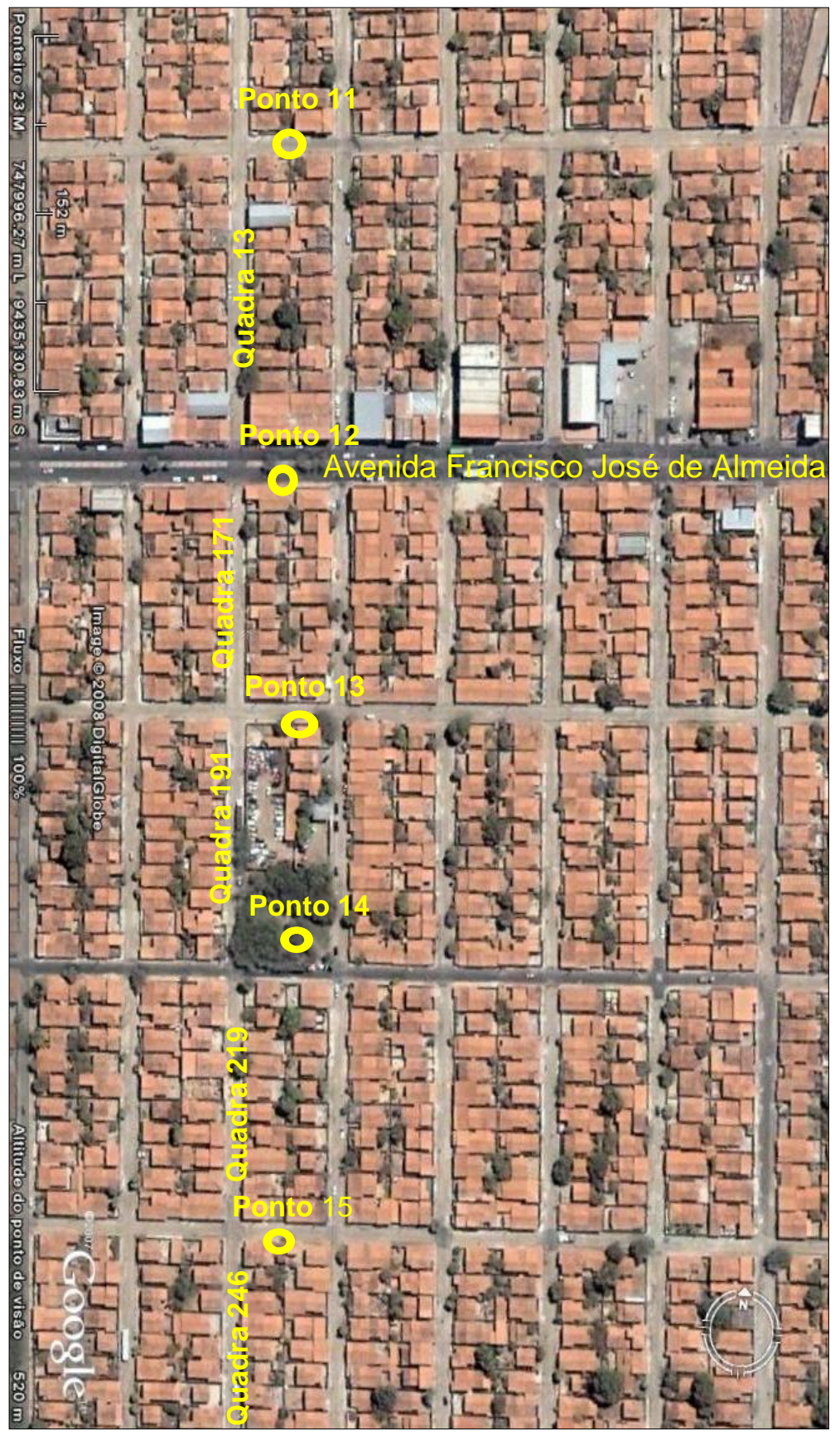

Figura 5. Vista Aérea do Bairro Dirceu Arcoverde - Pontos de Coletas Fonte: Google Earth, 2009

\subsection{Coleta de dados climáticos}

Em cada bairro estudado, foram escolhidos cinco pontos de coleta de dados, identificados com a utilização de Base Cartográfica da Cidade, fotografias aéreas, imagens de satélites, receptores GPS Autônomos e visitas "in loco". 


\section{INFLUÊNCIA DA VEGETAÇÃO EM VARIÁVEIS CLIMÁTICAS: ESTUDO EM BAIRROS DA}

CIDADE DE TERESINA, PIAUÍ

Nos 15 pontos analisados, sendo cinco pontos em cada um dos três bairros estudados, foram realizadas medições de temperatura e de umidade do ar, com auxílio de termo-higrômetros digitais nos horários de 9 h, 15h, e 21 h, conforme padrão internacional da Organização Meteorológica Mundial (OMM), durante sete dias consecutivos, nos meses de outubro de 2008 e março de 2009, que abrangem os períodos seco (verão) e chuvoso (inverno), respectivamente. No período seco as medições foram realizadas nos dias 8, 9 $10,11,12$, 13 e 14 de outubro e, no período chuvoso nos dias 25, 26, 27, 28, 29, 30 e 31 de março.

Para o registro da temperatura e da umidade relativa do ar nos pontos de coletas, foram utilizados termo-higrômetros digitais da Marca Instrutherm, Modelo Thal-300, devidamente aferidos. $O$ instrumento utilizado apresenta para a medida da temperatura, uma faixa de 0 a $50^{\circ} \mathrm{C}$, com resolução de $0,1^{\circ} \mathrm{C}$ e precisão de $0,5^{\circ} \mathrm{C}$. Nas medidas da umidade relativa do ar o equipamento apresenta faixa de 10 a $95 \% \mathrm{RH}$, com resolução de $0,1 \% \mathrm{RH}$ e precisão de $\pm 4 \%$ e $\pm 1,2 \mathrm{RH} \%$ para umidades inferiores e iguais ou superiores a $70 \%$, respectivamente.

Os pontos amostrais selecionados no campo foram plotados no mapa para determinação do campo térmico, proporcionando a verificação da relação entre a temperatura do ar e as áreas verdes. Foi adotada a metodologia utilizada por Shashua-Bar e Hoffman (2000), na qual são tomados dois pontos com características distintas, sendo um ponto com abundante vegetação e outro ponto com características áridas. O efeito moderador da temperatura foi analisado por meio da correlação dos dados coletados no ponto com vegetação e nos pontos de referência (sem vegetação).

Para os parâmetros temperatura e umidade relativa do ar, 0 delineamento experimental foi inteiramente casualizado em arranjo fatorial $3 \times 2 \times 3$, em que os bairros estudados (Pedra Mole, Jóquei Clube e Dirceu Arcoverde) representam o fator 1 , as estações do ano, caracterizadas na região nordeste do Brasil como seca e chuvosa, o fator 2 e os horários de coleta $(9,15$ e 21 horas), o terceiro fator. Foi feita análise de variância e 
quando se observou interação entre os fatores, foram feitos os desdobramentos das interações, duplas ou tripla, entre os fatores. Para avaliar os efeitos dos fatores, isolados ou combinados, foram realizados testes estatísticos de comparação de médias, utilizando-se os procedimentos do software Statistical Analysis System (SAS), segundo Sampaio (2010).

\section{RESULTADOS E DISCUSSÃO}

\subsection{Análise das variáveis climáticas}

O comportamento da temperatura do ar, nos três bairros (média dos cinco pontos), para as duas estações (seca e chuvosa), considerando os horários de 9 h, 15 h e 21 h, estão apresentados nas Figuras 6 e 7.

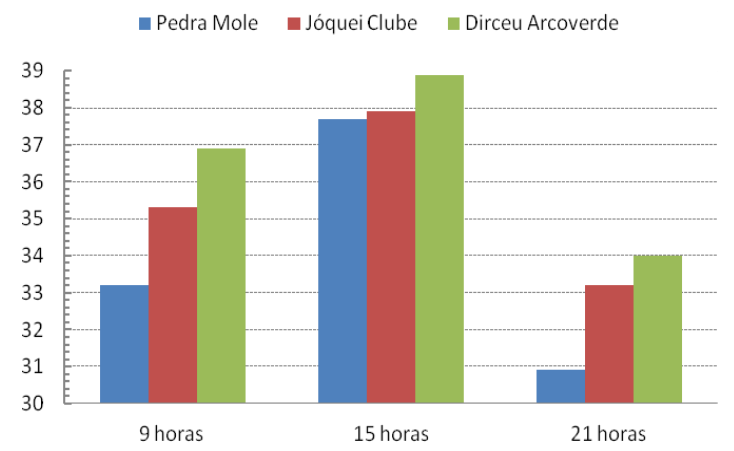

Figura 6. Comportamento da temperatura do ar, relacionado à estação seca, nos três horários, para os bairros estudados.

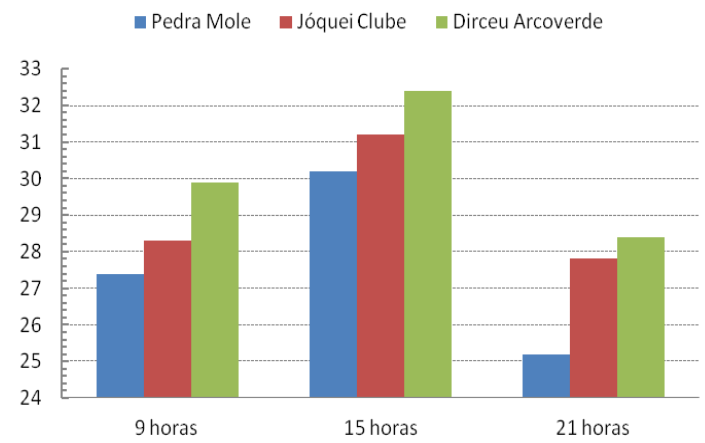

Figura 7. Comportamento da temperatura do ar, relacionado à estação chuvosa, nos três horários, para os bairros estudados.

Foi constatado que para a estação seca, nas três áreas de estudo, os maiores valores de temperatura foram obtidos no turno da tarde (15 h) e que nos três horários de coleta, o bairro Dirceu Arcoverde apresentou a maior média de temperaturas. Enquanto que, no bairro Pedra Mole, foi registrada a menor média, com $30,9{ }^{\circ} \mathrm{C}$, às $21 \mathrm{~h}$ e a maior temperatura foi registrada no bairro Dirceu Arcoverde, com $38,9^{\circ} \mathrm{C}$, às $15 \mathrm{~h}$, o que representa uma amplitude térmica de $8{ }^{\circ} \mathrm{C}$.

Já na estação chuvosa, foi observada a mesma tendência da estação seca, com os maiores valores registrados no horário de $15 \mathrm{~h}$ e os menores, no horário de $21 \mathrm{~h}$. sendo que, em todos os horários os menores valores foram 
registrados no bairro Pedra Mole e os maiores no bairro Dirceu Arcoverde. No entanto, ao se comparar com os valores registrados no período seco, observase que houve redução nos valores absolutos das temperaturas em todos os bairros e horários.

Nos gráficos das Figuras 8 e 9, é apresentado o comportamento da umidade do ar nos três bairros (média dos cinco pontos), para as duas estações (seca e chuvosa), considerando os horários de 9 h, 15 h e 21 h.

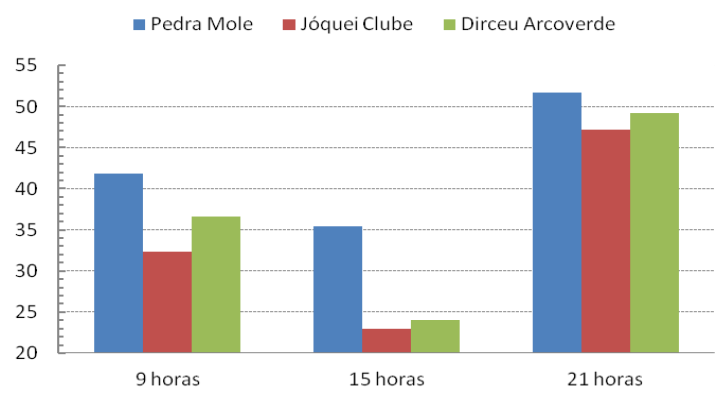

Figura 8. Comportamento da umidade do ar, relacionado ao período seco, nos três horários, para os bairros estudados.

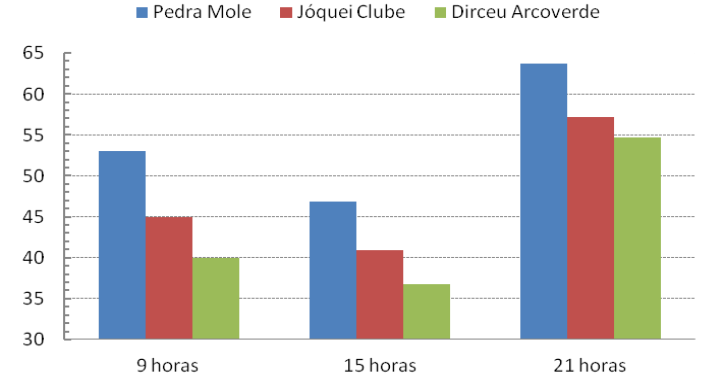

Figura 9. Comportamento da umidade do ar, relacionado ao período chuvoso, nos três horários, para os bairros estudados.

Para o período seco, foi observado que os maiores valores de umidade relativa do ar, para os três bairros, foram registrados no horário noturno $(21 \mathrm{~h})$ e os menores, à tarde (15 h) e, ainda, que o bairro Jóquei Clube, apesar de não possuir a área de estudo com a menor presença de vegetação no entorno, apresentou as menores médias por horário de coleta.

Foi possível observar que, diferentemente do que ocorreu no período seco, na estação chuvosa o bairro que apresentou, nos três horários, as menores médias de umidade relativa do ar foi o bairro Dirceu Arcoverde. Nos três bairros estudados foi constatado que os menores valores de umidade relativa ocorreram no horário das $15 \mathrm{~h}$, atingindo maiores valores às 21 horas. Enquanto que, às 9 horas, a umidade já dá sinais de redução certamente em função da incidência do sol, que nesse horário já é elevada.

Constatou-se que houve interação significativa entre os fatores bairros e horários de coleta, bem como entre bairros e estações do ano $(P<0,05)$ para temperatura e umidade relativa do ar. 


\section{INFLUÊNCIA DA VEGETAÇÃO EM VARIÁVEIS CLIMÁTICAS: ESTUDO EM BAIRROS DA}

CIDADE DE TERESINA, PIAUÍ

As temperaturas dentro dos três horários estudados (9, 15 e 21 horas) tiveram o mesmo comportamento, sendo maiores no bairro Dirceu Arcoverde, seguido pelo bairro Jóquei Clube e bairro Pedra Mole (Tabela 2). O horário 15 horas, nos três bairros teve sempre temperaturas mais elevadas que o das 9 horas, tendo o de 21 horas as menores temperaturas médias do período estudado $(P<0,05)$. Considerando os três horários, a temperatura no bairro Pedra Mole variou em termos médio entre 28,03 e $33,91^{\circ} \mathrm{C}$, enquanto no bairro Jóquei, a oscilação foi na faixa de 30,5 a $34,56{ }^{\circ} \mathrm{C}$ e no Dirceu Arcoverde, entre 31,21 e $35,67{ }^{\circ} \mathrm{C}$. Assim, ao se fazer o confronto das temperaturas com menores e maiores valores, que coincide com os bairros dotados de menores e maiores áreas com vegetação, observa-se diferença média de 2,67 ㄷ, correspondendo aos valores de 3,08, 1,76 e 3,18 $\circ$, respectivamente para os horários de 9, 15 e 21 horas. Este aspecto denota a influência da vegetação nas temperaturas ambientais das cidades.

Para a umidade relativa do ar (Tabela 2), foi observado que no horário das 9:00 e de 21:00 horas, não há diferença nos valores entre o bairro Jóquei Clube e bairro Dirceu Arcoverde, enquanto o bairro Pedra Mole apresenta maiores valores nos três horários. No horário das 15 horas, quando a radiação solar é mais intensa e as temperaturas atingem altos valores, o bairro Pedra Mole apresenta maior valor de umidade relativa do ar, seguido dos bairros Jóquei Clube e Dirceu Arcoverde. No horário das 15 horas, o bairro Jóquei Clube apresenta maior valor que o bairro Dirceu Arcoverde. Nos três bairros, o valor da umidade relativa do ar foi maior às 21 horas, seguida das 9 e 15 horas.

É importante ressaltar que no bairro Pedra Mole, os lotes se caracterizam por terem taxa de ocupação próxima de 100\%, com as construções tendo apenas um pavimento e de baixo padrão. Porém, no entorno da área central apresenta vasta área com baixa densidade populacional, composta de imóveis de forma irregular com extensas áreas de vegetação de grande porte. Por outro lado, o bairro Dirceu Arcoverde tem como principais características, alta taxa de ocupação e ausência de vegetação arbórea, enquanto o bairro Jóquei Clube possui vias, em sua totalidade, pavimentadas 
(asfáltica / poliédrica). Porém, em termos de presença de vegetação se apresenta como meio termo entre o bairro Pedra Mole com extensas áreas verdes e bairro Dirceu Arcoverde com pouca vegetação arbórea. Estes aspectos observados nos três bairros são determinantes no comportamento das temperaturas obtidas no presente estudo, caracterizando a importância das áreas verdes na redução das temperaturas ambientais.

Tabela 2. Valores de temperatura e umidade relativa do ar em função dos Bairros e horários de coleta

\begin{tabular}{|c|c|c|c|}
\hline \multicolumn{4}{|c|}{ Temperatura $\left({ }^{\circ} \mathrm{C}\right)$} \\
\hline \multirow[t]{2}{*}{ Bairro } & \multicolumn{3}{|c|}{ Horário } \\
\hline & 9:00 h & $15: 00 \mathrm{~h}$ & 21:00 \\
\hline Pedra Mole & $30,31^{\mathrm{bC}}$ & $33,91^{\mathrm{ac}}$ & $28,03^{\mathrm{CC}}$ \\
\hline Jóquei & $31,80^{\mathrm{bB}}$ & $34,56^{\mathrm{ab}}$ & $30,50^{\mathrm{cB}}$ \\
\hline Dirceu Arcoverde & $33,39^{\mathrm{bA}}$ & $35,67^{\mathrm{aA}}$ & $31,21^{\mathrm{cA}}$ \\
\hline CV (\%) & & 2,21 & \\
\hline \multicolumn{4}{|c|}{ Relativa (\%) } \\
\hline Pedra Mole & $47,38^{\mathrm{bA}}$ & $41,10^{\mathrm{CA}}$ & $57,70^{\mathrm{aA}}$ \\
\hline Jóquei & $38,63^{\mathrm{bB}}$ & $31,92^{\mathrm{cB}}$ & $52,17^{\mathrm{ab}}$ \\
\hline Dirceu Arcoverde & $38,31^{\mathrm{bB}}$ & $30,31^{\mathrm{cc}}$ & $51,95^{\mathrm{aB}}$ \\
\hline CV (\%) & & 5,54 & \\
\hline
\end{tabular}

Médias, na mesma linha, seguidas da mesma letra minúscula e na coluna, seguidas de mesma letra maiúscula, não diferem entre pelo teste SNK $(\alpha=0,05)$.

Neste contexto, ressaltam-se os achados da literatura, envolvendo a interferência das áreas verdes na melhoria das condições ambientais. Assim, Mills (2008) afirma que o pesquisador inglês Luke Howard foi o primeiro a reconhecer o efeito que as áreas urbanas podem causar sobre o clima local e segundo Landsberg (2006, p. 95), nos primeiros registros meteorológicos, realizados por Howard, na cidade de Londres, já era possível identificar diferenças de clima entre as cidades e o campo, "que foram comentadas desde o pioneiro estudo específico do clima de uma cidade", por Howard, de 1833 e que, "[...] ainda continuam a ser tratadas nas monografias atuais sobre o clima de cidades".

Para Loboda e De Angelis (2005, p. 131), a qualidade de vida urbana, "está diretamente atrelada a vários fatores que estão reunidos na infraestrutura, no desenvolvimento econômico-social e àqueles ligados à questão ambiental", destacando-se as áreas vegetadas como fator primordial "para o bem-estar da 
população, pois influencia diretamente a saúde física e mental da população". A vegetação é tida como um indicador de qualidade ambiental, atuando, junto a outros indicadores, como qualidade do ar, da água, solos, fauna e clima, como "[...] elemento indispensável ao equilíbrio, seja na manutenção de algumas condições vigentes desejáveis seja nas ações que visem à melhoria da qualidade de vida em áreas mais comprometidas" (JESUS; BRAGA, 2005, p. 208).

No presente estudo, em que os três bairros selecionados apresentam estruturas bem diferenciadas em termos, principalmente de áreas vegetadas, fica evidenciado o efeito do ambiente, tanto nos parâmetros temperatura ambiental como na umidade relativa do ar.

Também, outros fatores podem contribuir nas condições climáticas de uma cidade. Com esta perspectiva, Gomes e Soares (2004, p. 28) relacionam fatores degradantes de um ambiente, comumente encontrados nas cidades, como: "[...] sujeira; trânsito; concentração populacional demasiada; construções desordenadas; ausência de elementos naturais como solo permeável, água e vegetação; bem como os diversos tipos de poluição em todas as suas dimensões são considerados". Com o crescimento da população urbana, cresce na mesma proporção a necessidade de mais áreas construídas para suprir as necessidades da sociedade, ocasionando, dessa forma, modificações no ambiente.

Para Schlee (2001), o ser humano ao atuar em determinada área, contribui para modificar os fatores climáticos locais, a partir de ações como, terraplanagem, desmatamento e impermeabilização do solo. A expansão urbana modifica a paisagem natural, interferindo em seus elementos, considerando que, "tanto o crescimento horizontal quanto o vertical das cidades ocorrem em detrimento da qualidade dos recursos naturais (solo, água, ar e organismos) e dos espaços livres" (BUCCHERI FILHO; NUCCI, 2006, p. 48).

Sobre o fenômeno da urbanização, Labaki et al. (2011, p. 1) o consideram crescente e global, afirmando que, nas últimas décadas, "as cidades apresentaram grande crescimento da população, do espaço e de 


\section{INFLUÊNCIA DA VEGETAÇÃO EM VARIÁVEIS CLIMÁTICAS: ESTUDO EM BAIRROS DA}

CIDADE DE TERESINA, PIAUÍ

atividades, transformando drasticamente tanto 0 ambiente natural como 0 ambiente construído", acarretando, muitas vezes, prejuízo na qualidade de vida de seus habitantes. Na cidade de Cuiabá, Mato Grosso, por exemplo, que possui altas temperaturas no verão, são percebidos os problemas provenientes da urbanização. Na visão de Barros; Nogueira e Musis (2010, p. 156), a cidade de Cuiabá, de antes "[...] conhecida por 'Cidade Verde' pelos extensos fragmentos de cerrado presentes em toda a área urbana, vem sofrendo uma acelerada atividade imobiliária sem garantias de preservação das áreas verdes [...]", sendo, então, necessários, segundo os citados autores, estudos voltados para o conforto ambiental, principalmente de espaços livres urbanos.

No caso do presente estudo, os bairros Pedra Mole, Jóquei Clube e Dirceu Arcoverde, além da vegetação, apresentam estruturas diferentes, desde o tamanho dos lotes, pavimentação, taxa de ocupação, tipos de construção, pavimentação asfáltica, dentre outros, que interferem nas condições climáticas. Neste sentido, Stramandinoli (2008, p. 75) destaca que o maior índice de área pavimentada contribui para a redução da umidade e aumento de temperatura, considerando que, "a predominância de áreas pavimentadas sobre áreas de cobertura natural produz também uma superfície com elevada impermeabilidade, gerando grandes superfícies com rápido escoamento de águas com uma evapotranspiração quase nula". Em pesquisa desenvolvida na cidade de Curitiba, Paraná, no bairro do Bacacheri, foi constatado que, em apenas oito anos, quase 47 ha de lotes, em que havia predomínio de vegetação arbustiva e rasteira, passaram a ser solo impermeável e com edificações, refletindo na redução da qualidade ambiental (DIAS; NUCCI; VALASKI, 2014).

Assim, em estudo similar ao da presente pesquisa, Moura; Zanella e Sales (2010, p. 187), na cidade de Fortaleza, observaram que os horários de 14 e de 15 horas foram os mais críticos, em questão de desconforto térmico, ocorrendo "possivelmente, pelas elevadas taxas de radiação incidente na superfície urbana de Fortaleza pela manhã e sua devolução à tarde [...] 


\section{INFLUÊNCIA DA VEGETAÇÃO EM VARIÁVEIS CLIMÁTICAS: ESTUDO EM BAIRROS DA}

CIDADE DE TERESINA, PIAUÍ

associado à complexa realidade do espaço urbano, na sua morfologia e funcionalidade".

Segundo Lombardo (1985), a variação da temperatura superficial está relacionada ao tipo de solo urbano, observando-se que as maiores temperaturas ocorrem em locais de intenso crescimento vertical, alta densidade populacional e pouca cobertura vegetal. Desconsiderando o clima regional, pode-se afirmar que três fatores condicionam o clima urbano: a radiação, a forma urbana e as áreas verdes. As áreas verdes atuam como moderadoras das temperaturas urbanas.

Para, Gomes e Amorim (2003, p. 104), ao investigarem as condições térmicas e higrométricas existentes em uma praça densamente arborizada e outra desprovida de cobertura vegetal, na cidade de Presidente Prudente, São Paulo, os melhores índices de conforto térmico foram encontrados na praça mais arborizada, destacando, ainda, que "é principalmente sob altas temperaturas e baixa umidade que a arborização age eficientemente regulando as condições térmicas do ambiente". Nessa linha de pesquisa, Silva, Lopes e Lopes (2012), em medições realizadas em duas praças da cidade de Teresina, constataram que os menores valores de temperatura e maiores valores de umidade do ar, ocorreram na praça que apresentava maior área de vegetação. Estas constatações reforçam os achados do presente estudo, ressaltando o papel das áreas verdes na melhoria das condições climáticas em cidades que apresentam elevadas temperaturas ambientais.

Para Gomes e Soares (2003, p. 27), é certo que "medidas como a arborização de vias públicas, praças, vazios urbanos destinados à área verde, encostas e fundos de vale, principalmente com espécies nativas, podem contribuir significativamente na amenização do clima urbano e, sobretudo, para a melhoria da qualidade de vida humana". Destaca-se que as condições ambientais, como temperatura, umidade do ar, direção e velocidade predominante dos ventos, radiação solar e pluviometria, podem ser modificadas, consideravelmente, pela impermeabilização do solo e pela ausência de vegetação (PAULA; LABAKI, 2005). 
ALBUQUERQUE, M. M. ; LOPES, W. G. R.

INFLUÊNCIA DA VEGETAÇÃO EM VARIÁVEIS CLIMÁTICAS: ESTUDO EM BAIRROS DA CIDADE DE TERESINA, PIAUÍ

Os valores médios da temperatura e umidade relativa do ar em função das estações do ano (seca x chuvosa) nos bairros, Pedra Mole, Jóquei Clube e Dirceu Arcoverde estão apresentados na Tabela 3.

Constatou-se que os valores médios das temperaturas na época seca e umidade relativa do ar no período chuvoso nos três bairros estudados foram mais elevados $(P<0,05)$. Com relação aos bairros, tanto na estação seca como chuvosa, o bairro Dirceu Arcoverde apresentou temperaturas mais elevadas $(P<0,05)$, que o Jóquei, enquanto no bairro Pedra Mole foram observadas as menores temperaturas. Porém, para a umidade relativa do ar, o comportamento na estação chuvosa foi o inverso da temperatura, com o bairro Pedro Mole, tendo maiores valores médios, seguido do bairro Jóquei e bairro Dirceu Arcoverde $(\mathrm{P}<0,05)$. No período seco, o bairro Pedro Mole continuou apresentando maior valor, seguido do bairro Dirceu Arcoverde e do bairro Jóquei Clube $(P<0,05)$.

Tabela 3. Valores médios de temperatura e umidade relativa do ar em relação à época do ano e dos bairros estudados

\begin{tabular}{|c|c|c|}
\hline \multicolumn{3}{|c|}{ Temperatura $\left({ }^{\circ} \mathrm{C}\right)$} \\
\hline \multirow[t]{2}{*}{ Bairro } & \multicolumn{2}{|c|}{ Estação } \\
\hline & Chuva & Seca \\
\hline Pedra Mole & $27,58^{\mathrm{bC}}$ & $33,92^{\mathrm{ac}}$ \\
\hline Jóquei & $29,20^{\mathrm{bB}}$ & $35,49^{\text {ab }}$ \\
\hline Dirceu Arcoverde & $30,22^{\mathrm{bA}}$ & $36,62^{\mathrm{aA}}$ \\
\hline CV (\%) & & \\
\hline \multicolumn{3}{|c|}{ Umidade Relativa (\%) } \\
\hline Pedra Mole & $54,49^{\mathrm{aA}}$ & $42,97^{\mathrm{DA}}$ \\
\hline Jóquei & $47,68^{\mathrm{aB}}$ & $34,13^{\mathrm{bC}}$ \\
\hline Dirceu Arcoverde & $43,80^{\mathrm{ac}}$ & $36,59^{\mathrm{DB}}$ \\
\hline CV (\%) & \multicolumn{2}{|c|}{5,54} \\
\hline
\end{tabular}

Médias, na mesma linha, seguidas da mesma letra minúscula e na coluna, seguidas de mesma letra maiúscula, não diferem entre pelo teste SNK $(\alpha=0,05)$.

O bairro Pedra Mole, com extensas áreas verdes no entorno da área monitorada e com baixa densidade habitacional, foi o que apresentou os menores valores de temperaturas médias, tanto no período chuvoso $\left(27,58{ }^{\circ} \mathrm{C}\right)$, como no seco $\left(33,92{ }^{\circ} \mathrm{C}\right)$, enquanto para a umidade relativa do ar observou-se maior valor $(54,49 \stackrel{\circ}{\circ})$ no período chuvoso e $42,97^{\circ} \mathrm{C}$, no período seco. 
Já no bairro Dirceu Arcoverde ocorreu o oposto do que aconteceu no bairro Pedra Mole, apresentando as maiores médias de temperatura do ar, $30,22{ }^{\circ} \mathrm{C}$ no período chuvoso e $36,62 \stackrel{\circ}{\circ} \mathrm{C}$ no período seco, e os menores valores médios para umidade relativa, sendo $43,80 \%$ no período chuvoso e $36,59 \%$, no período seco. Esta constatação reforça que a escassez de vegetação arbórea, aliada à elevada densidade habitacional da região, são considerados fatores influenciadores deste resultado.

Nas áreas urbanas, segundo Mota (2003, p. 33), "em lugares pobres de vegetação as temperaturas alcançam valores máximos. Por outro lado, os valores mínimos são registrados em áreas verdes e reservatórios", o que reforça a importância das áreas verdes para a melhoria ambiental.

Gartland, (2010, p. 11) corrobora com esta ideia, afirmando que em áreas sem vegetação as temperaturas do ar são "[...] mais elevadas em consequência do aquecimento das superfícies urbanas, uma vez que superfícies artificiais absorvem mais calor do sol do que a vegetação natural".

Observa-se que o bairro Jóquei Clube apresenta o valor da média das temperaturas, intermediário aos valores dos dois outros bairros. No entanto, 0 valor da umidade, apesar de próximo ao encontrado no bairro Dirceu Arcoverde (diferença $=1,3{ }^{\circ} \mathrm{C}$ ) é inferior. Essa região que já perdeu bastante cobertura vegetal e, portanto, já não conta com o sombreamento das árvores suprimidas, ainda possui um número significativo de árvores nos imóveis.

Estes resultados são similares aos encontrados por Almeida Jr. (2005), na cidade de Cuiabá em Mato Grosso, onde foram coletados dados de temperatura, por meio de equipamentos situados, simultaneamente, à sombra de árvores e expostos ao sol, nos períodos chuvoso (inverno) e seco (verão). Comparando os valores de temperatura nas duas condições, concluiu-se que as áreas arborizadas proporcionam melhores condições de conforto ambiental e amenizam as altas temperaturas dos ambientes urbanos, reduzindo a temperatura entre 6 e $15^{\circ} \mathrm{C}$, no inverno, e entre 6 e $10^{\circ} \mathrm{C}$, no verão. 


\section{INFLUÊNCIA DA VEGETAÇÃO EM VARIÁVEIS CLIMÁTICAS: ESTUDO EM BAIRROS DA}

CIDADE DE TERESINA, PIAUÍ

\section{CONSIDERAÇÕES FINAIS}

Nos três locais estudados, os pontos com a presença de vegetação arbórea apresentaram os menores valores de temperatura e, em geral, os maiores valores de umidade relativa. Constatou-se que, enquanto no bairro Pedra Mole com extensas áreas verdes no entorno do local da pesquisa foram registrados os valores mais baixos de temperatura, o bairro Dirceu Arcoverde, que tem como característica a alta densidade habitacional, que restringe os espaços livres e suprime a vegetação, apresentou expressivo rigor térmico e as maiores diferenças de temperaturas entre o ponto de referência e ponto com presença arbórea.

Observou-se, também, que o bairro Jóquei Clube, que embora esteja passando por um intenso processo de verticalização, ainda é comum a presença de muitas árvores, principalmente, no interior dos lotes residenciais, apresentou valores intermediários. Além disso, o sombreamento proporcionado pelas edificações, também, contribui para amenizar o efeito da radiação solar, principalmente no período seco (verão).

As áreas verdes urbanas, além de protegerem 0 solo da impermeabilização, facilitando a infiltração das águas pluviais e reduzindo 0 escoamento superficial, controlam a poluição atmosférica e melhoram, também, as condições climáticas. Desta forma, destaca-se a importância da vegetação para a melhoria da qualidade ambiental dos aglomerados humanos, devendo ser uma preocupação dos gestores públicos e técnicos de projetos urbanísticos, a elaboração de planos que promovam a conservação, quando possível, da vegetação existente, e ainda, de projetos voltados para a implantação de espaços livres com mais área de vegetação e para a arborização urbana de ruas e avenidas.

\section{REFERÊNCIAS}

ABREU, Loyde Vieira de. Avaliação da escala de influência da vegetação no microclima por diferentes espécies arbóreas. 2008, 163 f. Dissertação (Mestrado em Engenharia Civil), Faculdade de Engenharia Civil, Arquitetura e Urbanismo, Universidade Estadual de Campinas, Campinas, 2008. 
ABREU, Loyde Vieira de; LABAKI, Lucila Chebel et al. Conforto térmico propiciado por algumas espécies arbóreas: avaliação do raio de influência através de diferentes índices de conforto. Ambiente Construído. Porto Alegre, v. 10, n. 4, p. 103-117, out./dez. 2010.

ALMEIDA JUNIOR, N. L. Estudo de Clima Urbano: uma proposta metodológica. 2005, 94 f. Dissertação (Mestrado em Física e Meio Ambiente), Departamento de Física, Instituto de Ciências Exatas e da Terra, Universidade Federal do Mato Grosso, Cuiabá, 2005.

ANDRADE, Carlos Sait P. de. O calor descortinando paisagens: Um "olhar" sobre a cidade de Teresina. In: VASCONCELOS, José Gerardo; ADAD, Shara Jane Holanda Costa (Org.). Coisas de Cidade. Fortaleza: Editora UFC, 2005.

BARBOSA, Ricardo V.R.; BARBIRATO, Gianna M.; VECCHIA, Francisco A. S. Vegetação urbana: análise experimental em cidade de clima quente e úmido. In: ENCONTRO NACIONAL DE CONFORTO NO SOBRE CONFORTO NO AMBIENTE CONSTRUÍDO. 7., 2003. Curitiba, Anais... Curitiba: ANTAC, 2003.

BARROS, Marcelo Paes de; Nogueira, Marta Cristina Jesus Albuquerque; MUSIS, Carlo Ralph de. O projeto de parque urbano e os riscos da exposição ao calor. Ambiente Construído, Porto Alegre, v. 10, n. 2, p. 147-156, abr./jun. 2010.

BASTOS, Edson Alves; ANDRADE JÚNIOR Aderson Soares de. Boletim agrometeorológico de 2010 para o município de Teresina, PI. Teresina: Embrapa Meio-Norte, 2011.

BUCCHERI Filho, Alexandre Theobaldo; NUCCl, João Carlos. Espaços Livres, Áreas Verdes e Cobertura Vegetal no Bairro Alto da XV, Curitiba/PR. Revista do Departamento de Geografia, São Paulo, n.18, p. 48-59, 2006.

CASTELO BRANCO, Aline Elvas. Urbanização e Clima em Teresina. Caderno de Teresina, Teresina, ano 15, n.35. mar. 2003, p. 10-15.

CASTELO BRANCO, Aline Elvas; ARAÚJO, Virginia Maria Dantas de. O desenho urbano e sua relação com o microclima: um estudo comparativo entre duas áreas centrais de Teresina. In: ENCONTRO NACIONAL DE CONFORTO NO SOBRE CONFORTO NO AMBIENTE CONSTRUÍDO. 6., 2001. Salvador, BA, Anais... São Pedro: ANTAC, 2001.

COSTA, Angelina Dias Leão. Análise bioclimática e investigação do conforto térmico em ambientes externos: uma experiência no bairro de Petrópolis em Natal/RN. 2003,179 p. Dissertação (Mestrado em Arquitetura e Urbanismo). Universidade Federal do Rio Grande do Norte. Natal, 2003. 
DACANAL, Cristiane; LABAKI, Lucila; SILVA, Talita Meulman Leite da. Vamos passear na floresta! O conforto térmico em fragmentos florestais urbanos. Ambiente Construído. Porto Alegre, v. 10, n. 2, p. 115-132, abr./jun. 2010.

DIAS, Mariana Andreotti; NUCCI, João Carlos; VALASKI, Simone. Classificação da paisagem do bairro do Bacacheri (Curitiba, Paraná) com base na cobertura do solo. Revista Ra'e Ga, Curitiba, v.31, p.146-163, dez. 2014.

DUARTE, Denise Helena Silva; SERRA, Geraldo Gomes. Padrões de ocupação do solo e microclimas urbanos na região de clima tropical continental brasileira: correlações e proposta de indicador. Ambiente Construído. Porto Alegre, v.3, n.2, p.7-20, abr./jun. 2003

FEITOSA, Sonia Maria Ribeiro et al. Consequências da Urbanização na Vegetação e na Temperatura da Superfície de Teresina - Piauí. REVSBAU, Piracicaba - SP, v.6, n.2, p.58-75, 2011.

FREITAS, Edmilson Dias de; DIAS, Pedro Leite da Silva. Alguns efeitos de áreas urbanas na geração de uma ilha de calor. Revista Brasileira de Meteorologia, São José dos Campos, SP, v. 20, n.3, p. 355-366, 2005.

FROTA, Anésia Barros; SHIFFER, Sueli Ramos. Manual de conforto Térmico: arquitetura, urbanismo. 5. ed. São Paulo: Studio Nobel, 2001.

GARTLAND, Lisa. Ilhas de calor: como mitigar zonas de calor em áreas urbanas. São Paulo: Oficina de Textos, 2010.

GOMES, Marcos Antônio Silvestre; SOARES, Beatriz Ribeiro A vegetação nos centros urbanos: considerações sobre os espaços verdes em cidades médias brasileiras. Estudos Geográficos, Rio Claro, v.1, n.1, p. 19-29, jun. 2003.

GOMES, Marcos Antônio Silvestre; SOARES, Beatriz Ribeiro. Reflexões sobre qualidade ambiental urbana. Estudos Geográficos, Rio Claro, v. 2, n. 2, p. 21 30, jul-dez. 2004.

GOMES, Marcos Antônio Silvestre; AMORIM, Margarete Cristiane de Costa Trindade. Arborização e conforto térmico no espaço urbano: estudo de caso nas praças públicas de Presidente Prudente (SP). Caminhos de Geografia. v. 7, n. 10, p. 94-106, set. 2003.

IBGE - Instituto Brasileiro de Geografia e Estatística. Cidades @. 2015. Disponível em: <http://www.ibge.gov.br/cidadesat/topwindow.htm?1>. Acesso em: 30 dez. 2015.

JESUS, Silvia Cristina de; BRAGA, Roberto. Análise espacial das áreas verdes urbanas da estância de águas de São Pedro. Caminhos de Geografia, Uberlândia, v. 18, n. 16, p. 207- 224, out. 2005. 
INFLUÊNCIA DA VEGETAÇÃO EM VARIÁVEIS CLIMÁTICAS: ESTUDO EM BAIRROS DA

LABAKI, Lucila Chebel et al. Vegetação e conforto térmico em espaços urbanos abertos. Fórum Patrimônio, Belo Horizonte, v. 5, n. 1, 2011.

LAMAS, José M. Ressano Garcia. Morfologia urbana e desenho da cidade. 3. ed. Lisboa: Fundação Calouste Gulbekian, 2004.

LANDSBERG, H. E. O clima das cidades. Revista do Departamento de Geografia, São Paulo, n.18, p. 95-111, 2006.

LIMA, A.M.L.P.; CAVALHEIRO, F.; NUCCI, J.C.; SOUZA, M.A.L.B.; FIALHO, N. O; DEL PICCHIA, P.C.D. Problemas de utilização na conceituação de termos como espaços livres, áreas verdes e correlatos. In: CONGRESSO BRASILEIRO SOBRE ARBORIZAÇÃO URBANA, 2, São Luís/MA. Anais... São Luís: Sociedade Brasileira de Arborização Urbana, 1994. p. 539-550.

LIMA, Iracilde Maria de Moura Fé. Teresina: Urbanização e Meio Ambiente. Scientia et Spes. Teresina, ano 1, n. 2, p. 181-206, 2002.

LOBODA, Carlos Roberto; DE ANGELIS, Bruno Luiz Domingos. Áreas verdes públicas urbanas: conceitos, uso se funções. Ambiência. Guarapuava, PR, v.1, n. 1, p. 125-139, jan./jun., 2005.

LOMBARDO, M. A. O clima e a cidade. In: ENCONTRO NACIONAL DE CONFORTO NO SOBRE CONFORTO NO AMBIENTE CONSTRUÍDO. 4. 1997. Salvador, BA, Anais... Salvador: ANTAC, 1997, p. 59-62. 1 CD.

Hucitec, 1985.

Ilhas de calor nas metrópoles: o exemplo de São Paulo. São Paulo:

MACHADO, R. R. B.; PEREIRA, E. C. G.; ANDRADE, L. H. C. Evolução temporal (2000-2006) da cobertura vegetal da zona urbana do município de Teresina - Piauí - Brasil. REVSBAU. Piracicaba - SP, n. 3, v. 5, 2010, p. 97112.

MASCARÓ, Lúcia Elvira Alicia Raffo de; MASCARÓ, Juan Luis. Vegetação Urbana. Porto Alegre: L. Mascaró, J. Mascaró, 2002. 242 p.

MOTA, S. Urbanização e Meio Ambiente. 3. ed. Rio de Janeiro: ABES, 2003.

MILLS, G. Luke Howard and the climate of London. Weather, v. 63, n. 4, Abril, 2008.

MOURA, Marcelo de Oliveira; ZANELLA, Maria Elisa; SALES, Marta Celina Linhares. Conforto térmico em Fortaleza-CE. Revista da ANPEGE. Fortaleza, v. 6, p. 177-189, jan./dez., 2010. 
PAIVA, João Paulo Matias. Análise Microclimática em Conjuntos Habitacionais: o caso do Conjunto Ceará - Fortaleza/CE. 2010, 150 p. Dissertação (Mestrado em Geografia). Universidade Estadual do Ceará. Fortaleza, 2010.

PAULA, Roberta Zakia Rigitano de; LABAKI, Lucila Chebel. A vegetação e o conforto térmico do ambiente construído: um estudo sobre a avaliação de conforto. In: ENCONTRO NACIONAL DE CONFORTO NO AMBIENTE CONSTRUÍDO, 8, 2005. Maceió, AL, Anais... Maceió: ANTAC, 2005, p. 14241430.

PAZ, Luiz Hildebrando Ferreira. A influência da vegetação sobre o clima de Palmas/TO. 2009, 169 p. Dissertação (Mestrado em Arquitetura e Urbanismo), Universidade de Brasília - UNB, Brasília, 2009.

SALES, Maria do Socorro T. Melo. Educação Ambiental: a preservação do verde na zona urbana na cidade de Teresina-PI. 2003, 215 p. Dissertação (Mestrado em Desenvolvimento e Meio Ambiente), Universidade Federal do Piauí - UFPI, Teresina, 2003.

SAMPAIO, Ivan Barbosa Machado. Estatística aplicada à experimentação animal. Belo Horizonte: FEPMVZ - Editora, 2010

SCHLEE, Andrey Rosenthal. O clima e a arquitetura brasileira. Ciência \& Ambiente. n. 22, p. 19-34, jan./jun., 2001.

SHASHUA-BAR, L.; HOFFMAN, M. E. Vegetation as a Climatic Component in the Design of a Urban Street: An Empirical Model for Predicting the Cooling Effect of Urban Green Areas with Trees. Energy and Buildings, v. 31, p. 221235, apr. 2000.

SILVA, Lucia Sousa; TRAVASSOS, Luciana. Problemas ambientais urbanos: desafios para a elaboração de políticas públicas integradas. Cadernos Metrópole, São Paulo, n. 19, p. 27-47, $1^{0}$ sem. 2008.

SILVA, Guilhermina Castro. Expansão dos condomínios horizontais e loteamentos fechados em Teresina, Piauí: segregação, estratégias de marketing, valorização e especulação imobiliária. 2015, 109 p. Tese (Doutorado em Desenvolvimento e Meio Ambiente), Universidade Federal do Piauí - UFPI, Teresina, 2015.

SILVA, Guilhermina Castro; LOPES, Wilza Gomes Reis; LOPES, João Batista Influência da vegetação no conforto ambiental. Revista da Anpege, v.8, n.10, p.67-84, ago./ dez. 2012.

SILVEIRA, Ana Lúcia Ribeiro Camillo da. Parâmetros Bioclimáticos para avaliação de conjuntos habitacionais na região tropical subúmida do 
Brasil. 2007. 312 f. Tese (Doutorado em Arquitetura e Urbanismo) - Faculdade de Arquitetura e Urbanismo - Universidade de Brasília- UNB, Brasília, 2007.

SOUZA, Jussara Freire de; SILVA, Richarde Marques; SILVA Alexandro Medeiros. Influência do uso e ocupação do solo na temperatura da superfície: 0 estudo de caso de João Pessoa - PB. Ambiente Construído, Porto Alegre, v. 16, n. 1, p. 21-37, jan./mar. 2016.

STRAMANDINOLI, Cristina Malafaia Caetano. Análise da qualidade ambiental de espaços urbanos em clima tropical úmido: uma proposta metodológica para espaços residuais. 2008, 167 f. Tese (Doutorado em Ciências de Arquitetura), Faculdade de Arquitetura e Urbanismo da Universidade Federal do Rio de Janeiro - UFRJ, Rio de Janeiro, 2008. 